\title{
Access to safe drinking water and sanitation under International Law
}

\author{
Azer Kasumov \\ Riga Graduate School of Law, Riga, Latvia
}

At present, clean drinking water and sanitation have become the main problem of the world. Several countries face this problem much more frequently, and the issue is particularly alarming in developing countries and the countries located in the Torrid Zone. 'In mountain areas, people have to spend vast amounts of time walking long distances to fetch drinking water. And citizens of some African countries have to drink polluted water'. ${ }^{1}$ These problems must be priority issues of states because 'more than 884 million people lack access to clean drinking water and 2.6 billion people lack access to safe sanitation'. 'About 1.5 million children under the age of five die each year because of water-related and sanitation-related diseases'. ${ }^{3}$ Several projects have been implemented by the appropriate international organizations to meet people's needs and to solve sanitation problems. However, taking into consideration the seriousness of the issue, these measures are not enough or adequate. 'In some mountain regions, people still have to go 10 kilometers away for drinking water. It is possible to imagine the difficulty of the situation in winter times. In some parts of the world, drinkable water is brought by trucks and kept for several days. And unfortunately, in most cases the sanitation of the barrel that water is stored in is not ensured'.

Firstly, we should clarify whether clean drinking water and sanitation are a human right.

\footnotetext{
${ }^{1}$ Drinking water and sanitation, pg 1, Available on the internet at : http:/www.npc.gov.np/uploads/plans/20081228124658.12\%20Drinking\%20Water\%20a nd\%20Sanitation Last visited: November 6, 2011

${ }^{2}$ World Health Organization and UNICEF, Progress on Sanitation and drinking water, (2010 update), page 6-7. Available on the internet at:

http://www.wssinfo.org/fileadmin/user upload/resources/1278061137-

IMP report 2010 en.pdf Last visited: December 13, 2011.

${ }^{3}$ Ibid.

${ }^{4}$ It is author's observation
} 
Drinking water and sanitation or other relevant rights according to these can be found in several international documents. Drinking water has been specifically mentioned in the 'Convention on Elimination of All Forms of Discrimination against Women and the Convention of the Rights of the Child (1989)'. ' 'Article 24 (2) (c) of Convention of the Rights of the Child stipulates that: ... combat disease and malnutrition through the provision of adequate nutritious food and clean drinking water'. ${ }^{6}$ All these documents are legally binding on the states that ratify them. The above-mentioned international documents recognize the right to water and sanitation. At the same time, UN has adopted relevant resolutions. Furthermore, 'Human Rights Council of United Nations adopted the resolution "Human Rights and access safe drinking water and sanitation (A/HRC/15/L.14)'. From the context of this resolution it seems that drinking water and sanitation are recognized as a part of human rights. Before this, on '28 July, 2010, United Nations General Assembly adopted a resolution recognizing access to clean drinking water and sanitation as human rights'. ${ }^{7}$ Resolutions of the Human Rights Council are also legally binding on the states. The aim of the Resolution is to recognize human rights to water and sanitation by member states. There are resolutions related to drinkable water and sanitation in the Convention on Economic, Social and Cultural Rights (though in this convention there are not exact directions about drinking water and sanitation). Article 2 of CESCR stipulates: 'Each State Parties to the present Covenant undertakes to take steps individually and through international assistance and co-operations specially economic and technical, maximum of its available resources, with view to the achieving progressively the full realizations of the rights recognized in the present Covenant by all appropriate means including particularly adoption of legislative measures, ${ }^{8}$ According to this article, states are bound to take measures in national legislation if there would be any necessity connected with the rights in the convention. Furthermore, in conformity with Resolution of HRC of UN, countries have to interpret it in their national legislation. At present, a few states have adopted drinking water and sanitation as human rights in their national legislation, such as 'Kenya, Morocco, the United Kingdom, Kazakhstan, Uruguay, Iran etc. 'Nowadays national level water rights are protected by 17 constitutions, the most recent of which (Congo) explicitly recognizes "right to access to water as" guaranteed'. For this law to be more effective, it is important for it to be

\footnotetext{
${ }^{5}$ Article 24 of CRC, Article 14 of CEDAW.

${ }^{6}$ Brownlie's Documents on Human Rights, Oxford University press, NY 2010, pg 466

${ }^{7}$ By vote 122 favor, 0 against and 41 abstentions.

${ }^{8}$ Brownlie's Documents on Human Rights, Oxford University press, NY 2010, pg 371

${ }^{9}$ George S. McGraw, Defining and Defining the Right to Water and its Minimum Core: Legal Construction and the Role of National Jurisprudence, Loyola University Chicago
} 
recognized as domestic law. Sometimes the fundamental rights and freedoms, such as freedom of expression, that have been noticed in international law are violated by the states. Sometimes international law protection mechanisms are inefficient and the states do not have the opportunity or influence to fulfill the requirements of international law. That is why this right must be adopted by states on the Constitution level.

I believe that one of the periods of lack of drinking water is time of war. 'During the Second World War prisoners of war were sometimes forbidden to leave their quarters during the night'. ${ }^{10}$ Sometimes water pipes or other water holding objects are destroyed by enemy fighters in war. When civilians and combatants are taken captive by the enemy combatants, they need drinking water and sanitation. The human rights are applied only during peacetime and therefore it is not applicable during the international and non-international conflicts. It is right that when the active war starts, the International Humanitarian Law, which is lex special for the wartime, is applied. However, the process of ensuring human rights is not stopped during the war and parties of the war should guarantee the right to access to drinking water and sanitation along with other human rights. Also, meeting the water and sanitation needs of people who are in enemy captivity has been recognized by International Humanitarian Law.

The second mission is the control by the states in meting these obligations. While the state realizes its obligation, which is noted in the United Nations Organization's resolution, it must follow the principles of "availability, quality, accessibility". If these criteria are followed, it is possible to fulfill obligations. One of the principles of human rights, prohibition of discrimination, includes the structure of accessibility. While human rights to drinking water and sanitation are provided, discrimination must not be allowed. If people's rights to drinking water and sanitation are provided in a discriminatory way by the states, it is breach of the requirements of the Resolution. Paragraph 8 (c) of Resolution of Human Rights Council says: "to pay particular attention belonging to vulnerable and marginalized groups including by respecting the principles of non-discrimination and gender equality". ${ }^{11}$

School of Law 2011; Volume 8, Issue 1. Available on internet (westlawinternational database).

${ }^{10}$ Report of the International Committee of the Red Cross on its activities during Second World War, Volume 1, pg.263.

${ }^{11}$ The UN Human Rights Council, Resolution on Human rights and access to safe drinking water and sanitation (A/HRC/15/L.14), September, 2010. Available on the 
The basic human rights documents put obligations on the states that there must not be any discrimination while providing human rights which are specified in the conventions. The discrimination could be between big cities and villages. We cannot say whether the drinking water problem and sanitation are more important in cities or villages. This discrimination could be between riches and poor or between minority and majority of people. That is why such discrimination must not be allowed by the states.

Breaking the right to drinking water and sanitation could create limitations in use of other rights of people. It is not possible to get quality education in schools which have sanitation problems. Such situations cause serious diseases in students. So, not only sanitation rights of children but also their right to get a quality education are violated. According to the resolution of the Human Rights Council, a state has to provide people's necessities such as drinkable water and sanitation. But, it does not mean that only state agencies could undertake such measures. According to this resolution, private companies, non-governmental organizations or individuals could also provide maintenance of drinking water. There remains a question about what quantity of water should be provided in order to consider the state as having fulfilled its obligation. The right to water should cover the minimum personal needs. Of course more than this could be provided, but providing this necessity is the implementation of people's right to water. Minimum water necessity could be adopted in a different quantity for each state. That is why each country has to define minimum water necessity in its legislation by taking into account its climate and water necessity. Sanitary liability does not mean that state will provide all people with clean living space. People have to provide such conditions for themselves. The main duty of the state is to create a clean environment for people, for example, cleaning polluted lakes and other water, construction of a sewage system, etc. According to the strategic plan adopted by the state, non-governmental agencies could realize these activities, too. However, the state has to control the provisions for rights to drinking water and sanitation, because the state bears responsibility before the international law. Futhermore, access to clean drinking water and sanitation is not only a health issue, but also about honor and dignity of people. Depriving people of these rights must be considered as inhuman treatment against them. Lack of drinking water and sanitation could cause serious and incurable diseases. The European Court of Human Rights considers the captivity of

internet at: http://ap.ohchr.org/documents/dpage e.aspx?si=A/HRC/15/L.14; Last visited: December 12, 2011. 
imprisoned persons in non-sanitary and non-hygienic space as inhuman treatment. ${ }^{12}$

\section{Conclusion}

Solving the problem of drinking water and sanitation must be a priority for states. States could delay settlement of some social and economic problems because people could not wait for a long time for drinking water. Lack of drinking water causes serious sanitation problems. By implementing the resolutions adopted by the UN and other resolutions connected with drinking water and sanitation, states can create effective mechanisms. Otherwise, this resolution will remain an unimplemented piece of paper like other resolutions of the UN. Domestic laws dealing with human rights should recognize the right to water and sanitation such as other basic human rights. Besides, the United Nation system of relevant organizations (such as UNICEF, WHO, UNDP) should work effectively with states (some states recognize the right to water and sanitation) for incorporation of the right to water to the national legislation.

The states, which have much more serious problems in access to drinking water and sanitation, must act immediately to draft a strategic plan to tackle the issue. They must fulfill their obligations in accordance with this project. Although the UN resolution and other documents fail to state that these services should be free of charge, considering the importance of the issue and the circumstances, water and sanitation services must be freely accessible to every citizen of a state. Some countries may face some difficulty in providing this, but I believe that in order to prevent any kind of discrimination among its citizens, states must ensure this right free of any charge which could limit someone's access to such.

\section{References and Notes:}

1. Brownlie's Documents on Human Rights, Oxford University press, NY 2010, pg 466

2. George S. McGraw, Defining and Defining the Right to Water and its Minimum Core: Legal Construction and the Role of National Jurisprudence, Loyola University Chicago School of Law 2011; Volume 8, Issue 1. Available on internet (westlawinternational database).

3. Drinking water and sanitation, pg 1, Available on the internet at : http://www. npc.gov.np/uploads/plans/20081228124658.12\%20Drinking\%20Water\%20and\%20Sa nitation Last visited: November 6, 2011

\footnotetext{
${ }^{12}$ ECHR, Mammadov versus Azerbaijan . Available on HUDOC database: http://cmiskp.echr.coe.int/tkp197/search.asp?skin=hudoc-en
} 
4. World Health Organization and UNICEF, Progress on Sanitation and drinking water, (2010 update), page 6-7. Available on the internet at: http://www.wssinfo.org/ fileadmin/user_upload/resources/1278061137-JMP_report_2010_en.pdf Last visited: December 13, 2011.

5. Report of the International Committee of the Red Cross on its activities during Second World War, Volume 1, pg.263.

6. European Court on Human Rights, Mammadov versus Azerbaijan. Available on HUDOC database: http://cmiskp.echr.coe.int/tkp197/search.asp?skin=hudoc-en

7. International Covenant on Economic, Social and Cultural Rights (ICESCR), 1966, Article 2, 11.

8. Convention of the Rights of the Child (1989), Article 24.

9. African Chater on Human and People's Rights (ACHPR), 1981,

10. International Convention on the Elimination of All Forms of Discrimantion Against Women (CEDAW), Article 14. 1979,

11. United Nations General Assembly, Resolution "Access clean drinking water and sanitation" (A/64/L.63/Rev.1), July 28, 2010.

12. The UN Human Rights Council, Resolution on Human rights and access to safe drinking water and sanitation (A/HRC/15/L.14), September, 2010. Available on the internet at: http://ap.ohchr.org/documents/dpage e.aspx?si=A/HRC/15/L.14; Last visited: December 12, 2011.

\title{
SUMMARY
}

\section{Access to safe drinking water and sanitation under International Law}

\author{
Azer Kasumov
}

\author{
Riga Graduate School of Law, Riga, Latvia
}

The Article briefly describes the importance and significance of water to human life. The article comprises a legal analysis of whether such a right is present in international legal instruments and importance of implementation to national legislation of member states of United Nations. While examining water and sanitation as a human right, the article also briefly touches on the Constitutional provisions of some member states and the interpretations of relevant resolutions of the UN. The next part of the article addresses the relevance linking of human rights and water and sanitation. And from the human rights perspective, the article strongly advocates that water falls in the category of a human right and not just a human need. The author concluded that the rights to water and sanitation have not yet explicitly entered to human rights spheres.

Key words: water, sanitation, human rights, legislation, United Nations 